\title{
MENGIDENTIFIKASI TAHAPAN-TAHAPAN METODOLOGI ANALISIS AUDIT SISTEM INFORMASI
}

\author{
Winariyani \\ 175100007 \\ Fakultas Komputer \\ winariyani.student@umitra.ac.id
}

\begin{abstract}
Audit Sistem Informasi merupakan proses pengumpulan dan pengevaluasian buktibukti untuk menentukan apakah suatu sistem aplikasi komputerisasi telah menetapkan dan menerapkan sistem pengendalian intern yang memadai, semua aktiva dilindungi dengan baik atau tidak disalahgunakan serta terjaminnya integritas data, keandalan serta efektifitas dan efisiensi penyelenggaraan sistem informasi berbasis komputer.
\end{abstract}

Disini kita akan mengidentifikasi tentang tahapan-tahapan metodologi analisis audit sistem informasi. Audit sistem informasi melakukan tinjauan atas pengendalian untuk menilai kesesuaiannya dengan kebijakan dan prosedur pengendalian serta efektivitas dalam menjaga aset perusahaan. Dengan kata lain Audit Sistem Informasi adalah proses pengumpulan dan pengevaluasian bukti-bukti untuk membuktikan dan menentukan apakah sistem aplikasi komputerisasi yang digunakan telah menetapkan dan menerapkan sistem pengendalian intern yang memadai, apakah aset organisasi sudah dilindungi dengan baik dan tidak disalah gunakan, apakah mampu menjaga integritas data, kehandalan serta efektifitas dan efisiensi penyelenggaraan sistem informasi berbasis komputer.

Kata Kunci : Metodologi Analisis Audit SI. 


\section{A. PENDAHULUAN}

Audit Sistem Informasi merupakan proses pengumpulan dan pengevaluasian bukti-bukti untuk menentukan apakah suatu sistem aplikasi komputerisasi telah menetapkan dan menerapkan sistem pengendalian intern yang memadai, semua aktiva dilindungi dengan baik atau tidak disalahgunakan serta terjaminnya integritas data, keandalan serta efektifitas dan efisiensi penyelenggaraan sistem informasi berbasis komputer (sanyoto,2017).

Didalam suatu perusahaan juga dibutuhkan peranan sistem, dimana peran sistem tersebut sangatlah penting bagi keperluan perusahaan. Sistem dapat membantu mempermudah sharing data antar aplikasi, alur administrasi sangat mudah dan jelas, mengurangi pengulangan data, membantu vendor mengembangkan sistem, dan juga memudahkan perawatan oleh sebab itu dibutuhkannya sebuah tahapan tahapan audit sistem informasi untuk memenuhi manfaat dari suatu sistem diatas. Terdapat tiga jenis audit yang biasanya dilakukan, yaitu: Audit keuangan, Audit sistem informasi, Audit operasional atau manajemen.

Disini kita akan mengidentifikasi tentang tahapan-tahapan metodologi analisis audit sistem informasi. Audit sistem informasi melakukan tinjauan atas pengendalian sistem informasi untuk menilai kesesuaiannya dengan kebijakan dan prosedur pengendalian serta efektivitas dalam menjaga aset perusahaan. Dengan kata lain Audit Sistem Informasi adalah proses pengumpulan dan pengevaluasian bukti-bukti untuk membuktikan dan menentukan apakah sistem aplikasi komputerisasi yang digunakan telah menetapkan dan menerapkan sistem pengendalian intern yang memadai, apakah aset organisasi sudah dilindungi dengan baik dan tidak disalah gunakan, apakah mampu menjaga integritas data, kehandalan serta efektifitas dan efisiensi penyelenggaraan sistem informasi berbasis komputer.

Ada 4 (empat) tujuan audit sistem informasi, yaitu: 
1. Mengamankan asset.

2. Menjaga integritas data.

3. Menjaga efektivitas sistem.

4. Mencapai efisiensi sumberdaya.

Menurut Weber (1999, p.55-57), metode audit meliputi:

\section{Auditing around the computer}

Merupakan suatu pendekatan audit dengan memperlakukan komputer sebagaiblack box, maksudnya metode ini tidak menguji langkahlangkah proses secara langsung, tetapi hanya berfokus pada masukan dan keluaran dari sistem komputer.

Kelemahan dari pendekatan ini jika lingkungan berubah, maka kemungkinan sistem itu berubah dan perlu penyesuaian sistem, sehingga auditor tidak dapat menilai apakah sistem masih berjalan dengan baik. Keunggulan dari pendekatan ini adalah pelaksanaan audit lebih sederhana, dan bagi auditor yang memiliki pengetahuan yang minim di bidang komputer dapat dilatih dengan mudah untuk melaksanakan audit.

\section{Auditing through the computer}

Merupakan suatu pendekatan audit yang berorientasi pada komputer dengan membuka black-box, dan secara langsung berfokus pada operasi pemrosesan dalam sistem komputer.

Keuntungan utama dari pendekatan ini adalah dapat meningkatkan kekuatan terhadap pengujian sistem aplikasi secara efektif, dimana ruang lingkup dan kemampuan pengujian yang dilakukan dapat diperluas sehingga tingkat kepercayaan terhadap kehandalan dari pengumpulan dan pengevaluasian bukti dapat ditingkatkan.

Kelemahan pendekatan audit ini diantaranya biaya yang dibutuhkan relatif tinggi serta membutuhkan keahlian dari sisi tehnik secara mendalam.

\section{Auditing with the computer} Merupakan suatu pendekatan audit dengan menggunakan komputer 
sendiri (audit software) untuk membantu melaksanakan langkahlangkah audit. Auditing sistem informasi berdasarkan komputer terdiri dari penggunaan komputer itu sendiri, teknik auditing dengan metode ini sangat berguna selama pengujian substantif atas file dan record suatu perusahaan. Sebaliknya, teknik auditing melalui komputer adalah teknik yang membantu dalam pengujian ketaatan.

\section{B. PEMBAHASAN / STUDI KASUS}

Dalam metodologi analisis audit sistem informasi untuk pengembangan sistem menggunakan metodologi analisis dan design sistem struktur (structured system analysis and design). Metodologi analisis dan desain terstruktur adalah metodologi yang digunakan pada tahap analisis dan tahap desain. Metodologi ini termasuk dalam kelompok data oriented methodologies yang menekankan pada karakteristik dari data yang akan diproses, lebih spesifik metodologi analisis dan desain terstruktur masuk dalam kategori data flow oriented methodologies dimana metodologi ini didasarkan kepada pemecahan dari sistem ke dalam modul-modul berdasarkan tipe elemen datadan tingkah laku logika modul tersebut didalam sistem. Dengan metodologi ini sistem secara logika dapat digambarkan secara logika dan digambarkan secara logika dari arus dta dan hubungan antar fungsinya didalam modul-modul sistem.

Audit sistem informasi dapat digolongkan dalam tipe atau jenis-jenis audit sebagai berikut :

1. Audit Laporan Keuangan (Financial Statement Audit) dalah audit yang dilakukan untuk amengetahui tingkat kewajaran laporan keuangan yang disajikan oleh perusahaan (apakah sesuai dengan standar akuntansi keuangan serta tidak menyalahi uji materialitas). Apabila sistem akuntansi organisasi yang diaudit merupakan sistem akuntansi 
berbasis komputer, maka dilakukan audit terhadap sistem informasi akuntansi apakah proses/mekanisme sistem dan program komputer telah sesuai, pengendalian umum sistem memadai dan data telah substantif.

2. Audit Operasional (Operational Audit) adalah audit terhadap aplikasi komputer terbagi menjadi tiga jenis, antara lain:

\section{Tahapan Metodologi Analisis:}

1. Kebijakan dan perencanaan sistem

\section{Analisis desain}

\section{Seleksi sistem}

\section{Implementasi sistem}

\section{- Kebijakan Perencanaan Sistem}

Merupakan landasan dan pedoman untuk mengembangkan sistem.

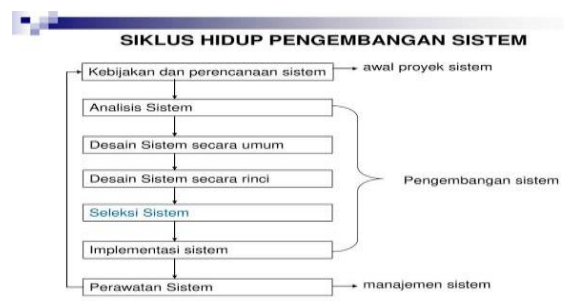

- Analisis Desain

Merupakan pengidentifikasian dan pengevaluasian bagaimana menggambarkan suatu sistem.

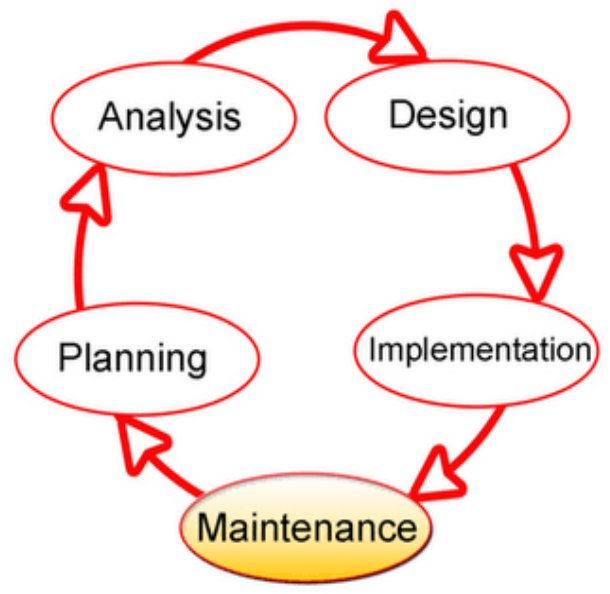

- $\quad$ Seleksi Sistem

Merupakan tahap seleksi memilih perangkat keras dan perangkat lunak untuk sistem informasi.

- Implementasi Sistem

Merupakan tahap penerapan sistem yang akan dilakukan jika sistem disetujui termasuk program yang telah dibuat pada tahap perancangan sistem agar siap untuk dioperasikan. 
Audit Sistem Informasi dapat dilakukan dengan berbagai macam tahap-tahap. Tahap-tahap audit terdiri dari 5 tahap sebagai berikut :

1. Tahap pemeriksaan pendahuluan

2. Tahap pemeriksaan rinci.

3. Tahap pengujian kesesuaian.

4. Tahap pengujian kebenaran bukti.

5. Tahap penilaian secara umum atas hasil pengujian.

Tahap Pemeriksaan Pendahuluan. Sebelum auditor menentukan sifat dan luas pengujian yang harus dilakukan, auditor harus memahami bisnis auditi (kebijakan, struktur organisasi, dan praktik yang dilakukan). Setelah itu, analisis risiko audit merupakan bagian yang sangat penting. Ini meliputi review atas pengendalian intern. Dalam tahap ini, auditor juga mengidentifikasi aplikasi yang penting dan berusaha untuk memahami pengendalian terhadap transaksi yang diproses oleh aplikasi tersebut. pada tahap ini pula auditor dapat memutuskan apakah audit dapat diteruskan atau mengundurkan diri dari penugasan audit.

* Tahap Pemeriksaan Rinci. Pada tahap ini auditnya berupaya mendapatkan informasi lebih mendalam untuk memahami pengendalian yang diterapkan dalam sistem komputer klien. Auditor harus dapat memperkirakan bahwa hasil audit pada akhirnya harus dapat dijadikan sebagai dasar untuk menilai apakah struktur pengendalian intern yang diterapkan dapat dipercaya atau tidak. Kuat atau tidaknya pengendalian tersebut akan menjadi dasar bagi auditor dalam menentukan langkah selanjutnya.

* Tahap Pengujian Kesesuaian. Dalam tahap ini, dilakukan pemeriksaan secara terinci saldo akun dan transaksi. Informasi yang digunakan berada dalam file data yang biasanya harus diambil menggunakan software CAATTs. Pendekatan basis data menggunakan CAATTs dan pengujian substantif untuk 
memeriksa integritas data. Dengan kata lain, CAATTs digunakan untuk mengambil data untuk mengetahui integritas dan keandalan data itu sendiri.

Tahap Pengujian Kebenaran Bukti. Tujuan pada tahap pengujian kebenaran bukti adalah untuk mendapatkan bukti yang cukup kompeten,. Pada tahap ini, pengujian yang dilakukan adalah (Davis at.all. 1981) :

1.Mengidentifikasi kesalahan dalam pemrosesan data.

2. Menilai kualitas data.

3.Mengidentifikasi ketidak

konsistennya suatu data.

4. Membandingkan data dengan perhitungan fisik .

5. Konfirmasi data dengan sumbersumber dari luar perusahaan.

Tahap Penilaian Secara Umum atas Hasil Pengujian. Pada tahap ini auditor diharapkan telah dapat memberikan penilaian apakah bukti yang diperoleh dapat atau tidak mendukung informasi yang diaudit. Hasil penilaian tersebut akan menjadi dasar bagi auditor untuk menyiapkan pendapatanya dalam laporan auditan. Auditor harus mengintegrasikan hasil proses dalam pendekatan audit yang diterapkan audit yang diterapkan. Audit meliputi struktur pengendalian intern yang diterapkan perusahaan, yang mencakup :

1. Pengendalian umum.

2. Pengendalian aplikasi, yang terdiri dari :

(a) Pengendalian secara manual.

(b) pengendalian terhadap output sistem informasi.

(c) Pengendalian yang sudah diprogram.

\section{ID SECURITY}

QWTD4452377-ASP-5244166 


\section{KESIMPULAN}

Kesimpulan Materi ini adalah Audit sistem informasi selain mendongkrak daya kinerja suatu perusahaan adalah kepentingan yang harus dimiliki instansi, dikarnakan audit mampu merapihkan dan mengurangi kerugian-kerugian yang tanpa kita sadari.

Audit Sistem Informasi adalah proses pengumpulan dan pengevaluasian bukti-bukti untuk membuktikan dan menentukan apakah sistem aplikasi komputerisasi yang digunakan telah menetapkan dan menerapkan sistem pengendalian intern yang memadai, apakah aset organisasi sudah dilindungi dengan baik dan tidak disalah gunakan, apakah mampu menjaga integritas data, kehandalan serta efektifitas dan efisiensi penyelenggaraan sistem informasi berbasis komputer.

1) Perencanaan audit menghasilkan identifikasi ruang lingkup dalam menerapkan manajemen resiko. Langkah audit keamanan informasi dilakukan pembuatan pernyataan, penentuan nilai bobot, dan penentuan nilai kematangan.

2) Pelaksanaan audit didapatkan dari hasil wawancara dalam menentukan dokumen yang diperlukan.

3)Penyalahgunaan username dan pass word.

4) Kurang adanya sumber daya manusia yang mengelola.

5) Tidak ada pencatatan mengenai insiden kelemahan keamanan

Tahapan Metodologi Analisis:

1. Kebijakan dan perencanaan sistem

2. Analisis desain

3. Seleksi sistem

4. Implementasi sistem

Dalam mengaudit sistem komputerisasi yang ada, audit ini dilakukan dengan mengevaluasi pengendalian umum dari sistem-sistem komputerisasi yang sudah diimplementasikan pada perusahaan tersebut secara keseluruhan. Saat melakuan pengujian-pengujian digunakan bukti untuk menarik kesimpulan dan memberikan rekomendasi kepada manajemen tentang hal-hal yang berhubungan 
dengan efektifitas, efisiensi, dan ekonomisnya sistem.

\section{E. DISKUSI}

Saya bersama teman saya bernama dwi Febriana mendiskusikan tentang Tahapan Analisis Metodologi Audit Sistem Informasi dengan sangat baik. Hasil diskusi dari materi ini adalah Data yang diolah menjadi sebuah informasi, merupakan aset penting dalam organisasi bisnis saat ini. Banyak aktivita operasi mengandalkan beberapa informasi yang penting. Informasi sebuah organisasi bisnis akan menjadi sebuah potret atau gambaran dari kondisi organisasi tersebut di masa lalu, kini dan masa mendatang. Jika informasi ini hilang akan berakibat cukup fatal bagi organisasi dalam menjalankan aktivitasnya. Sebagai contoh adalah jika data karyawan di keuangan hilang akibat rusak, maka informasi yang terkait akan hilang, misalkan siapa saja karyawan yang belum menerima gaji. Sehingga pihak keuangan akan benar-benar memperhatikan bagaimana menjaga keamanan datanya. Kehilangan data juga dapat terjadi karena tiadanya pengendalian yang memadai, seperti tidak adanya prosedur back-up file. Kehilangan data dapat disebabkan karena gangguan sistem operasi pemrosesan data, sabotase, atau gangguan karena alam seperti gempa bumi, kebakaran atau banjir.

\section{F. REFERENCE}

O. M. Febriani and A. S. Putra, "Sistem Informasi Monitoring Inventori Barang Pada Balai Riset Standardisasi Industri Bandar Lampung," J. Inform., vol. 13, no. 1, pp. 90-98, 2014.

[2] A. S. Putra, "Paperplain: Execution Fundamental Create Application With Borland Delphi 7.0 University Of Mitra Indonesia," 2018.

[3] A. S. Putra, "2018 Artikel Struktur Data, Audit Dan Jaringan Komputer,” 2018.

[4] A. S. Putra, "ALIAS MANAGER USED IN DATABASE DESKTOP STUDI CASE DB DEMOS." 

A.
S.
Putra, "COMPREHENSIVE SET OF PROFESSIONAL

FOR DISTRIBUTE COMPUTING.”

[6] A. S. Putra, "DATA ORIENTED RECOGNITION IN BORLAND DELPHI 7.0.”

[7] A. S. Putra, "EMBARCADERO DELPHI XE 2 IN GPUPOWERED FIREMONKEY APPLICATION."

[8] A. S. Putra, "HAK ATAS KEKAYAAN INTELEKTUAL DALAM DUNIA TEKNOLOGY BERBASIS REVOLUSI INDUSTRI 4.0.”

[9] A. S. Putra, "IMPLEMENTASI PERATURAN PERUNDANGAN UU. NO 31 TAHUN 2000 TENTANG DESAIN INDUSTRI BERBASIS INFORMATION TECHNOLOGY."

$\begin{array}{lr}\text { A. } & \text { S } \\ \text { "IMPLEMENTATION } & \text { OF } \\ \text { PARADOX DBASE." } & \end{array}$

[11] A.

S.

Putra, "IMPLEMENTATION OF TRADE SECRET CASE STUDY SAMSUNG MOBILE
[12]

A. S. Putra, "IMPLEMENTATION

PATENT FOR APPLICATION WEB BASED CASE STUDI WWW. PUBLIKLAMPUNG. COM."

[13] A.

S. Putra, "IMPLEMENTATION SYSTEM FIRST TO INVENT IN DIGITALLY INDUSTRY."

[14] A. S. Putra, "MANUAL REPORT \& INTEGRATED DEVELOPMENT ENVIRONMENT BORLAND DELPHI 7.0.”

[15] A. S. Putra, "PATENT AS RELEVAN SUPPORT RESEARCH.”

[16] A. S. Putra, "PATENT FOR RESEARCH STUDY CASE OF APPLE. Inc.”

[17] A. S. Putra, "PATENT PROTECTION FOR APPLICATION INVENT."

[18] A. S. Putra, "QUICK REPORT IN PROPERTY PROGRAMMING." A. S. Putra, "REVIEW CIRCUIT LAYOUT 
COMPONENT

REQUIREMENT ON ASUS NOTEBOOK."

[20] A. S. Putra, "REVIEW TRADEMARK PATENT FOR INDUSTRIAL

TECHNOLOGY BASED 4.0.”

[21] A. S. Putra, "TOOLBAR COMPONENT PALLETTE IN OBJECT

ORIENTED

PROGRAMMING.”

A. S. Putra, "WORKING

DIRECTORY SET FOR PARADOX 7."

[23] A. S. Putra, "ZQUERY CONNECTION

IMPLEMENTED

PROGRAMMING STUDI

CASE PT. BANK BCA Tbk."

[24] A. S. Putra, D. R. Aryanti, and

I. Hartati, "Metode SAW (Simple Additive Weighting) sebagai Sistem Pendukung Keputusan Guru Berprestasi (Studi Kasus: SMK Global Surya)," in Prosiding Seminar Nasional Darmajaya, 2018, vol. 1, no. 1, pp. 85-97.

[25] A. S. Putra and O. M. Febriani, "Knowledge Management
Online Application in PDAM Lampung Province," in Prosiding International conference on Information Technology and Business (ICITB), 2018, pp. 181-187.

[26] A. S. Putra, O. M. Febriani, and B. Bachry, "Implementasi Genetic Fuzzy System Untuk Mengidentifikasi Hasil Curian Kendaraan Bermotor Di Polda Lampung," SIMADA (Jurnal Sist. Inf. dan Manaj. Basis Data), vol. 1, no. 1, pp. 21-30, 2018.

[27] A. S. Putra, H. Sukri, and K. Zuhri, "Sistem Monitoring Realtime Jaringan Irigasi Desa (JIDES) Dengan Konsep Jaringan Sensor Nirkabel," IJEIS (Indonesian J. Electron. Instrum. Syst., vol. 8, no. 2, pp. 221-232.

[28] D. P. Sari, O. M. Febriani, and A. S. Putra, "Perancangan Sistem Informasi SDM Berprestasi pada SD Global Surya," in Prosiding Seminar Nasional Darmajaya, 2018, vol. 1, no. 1, pp. 289-294. 
